\title{
IL-10 and IL-22 in Mucosal Immunity: Driving Protection and Pathology
}

\author{
Hua-Xing Wei ${ }^{1}$, Baolong Wang ${ }^{1 *}$ and Bofeng $\mathrm{Li}^{2 \star}$ \\ 'Division of Life Sciences and Medicine, Department of Laboratory Medicine, The First Affiliated Hospital of USTC, University \\ of Science and Technology of China, Hefei, China, ${ }^{2}$ Division of Life Sciences and Medicine, Department of Medical Oncology, \\ The First Affiliated Hospital of USTC, University of Science and Technology of China, Hefei, China
}

OPEN ACCESS

Edited by:

Zhigang Tian,

University of Science and Technology

of China, China

Reviewed by:

Cai Zhang,

Shandong University, China

Jiacheng Bi,

Chinese Academy of Sciences

(CAS), China

${ }^{*}$ Correspondence:

Baolong Wang

wb/196555@163.com

Bofeng Li

libf@ustc.edu.cn

Specialty section:

This article was submitted to

NK and Innate Lymphoid Cell Biology,

a section of the journal

Frontiers in Immunology

Received: 03 April 2020

Accepted: 26 May 2020

Published: 26 June 2020

Citation:

Wei H-X, Wang B and Li B (2020)

IL-10 and IL-22 in Mucosal Immunity:

Driving Protection and Pathology.

Front. Immunol. 11:1315

doi: 10.3389/fimmu.2020.01315
The barrier surfaces of the gastrointestinal tract are in constant contact with various microorganisms. Cytokines orchestrate the mucosal adaptive and innate immune cells in the defense against pathogens. IL-10 and IL-22 are the best studied members of the $\mathrm{IL}-10$ family and play essential roles in maintaining mucosal homeostasis. IL-10 serves as an important regulator in preventing pro-inflammatory responses while IL-22 plays a protective role in tissue damage and contributes to pathology in certain settings. In this review, we focus on these two cytokines in the development of gastrointestinal diseases, including inflammatory bowel diseases (IBD) and colitis-associated cancer (CAC). We summarize the recent studies and try to gain a better understanding on how they regulate immune responses to maintain equilibrium under inflammatory conditions.

Keywords: IL-10, IL-22, IBD, colorectal cancer, ILC, inflammation

\section{INTRODUCTION}

The IL-10-related cytokine family includes several members, IL-10, IL-19, IL-20, IL-22, IL-24, IL-26, IL-28A/B, and IL-29, which also belong to the class $2 \alpha$-helical cytokines (1). IL-19, IL-20, IL-22, IL-24, and IL-26 also belong to the IL-20 sub-family. All members of the IL-10 cytokine family signal through heterodimeric receptors composed of an $\alpha$-chain and a $\beta$-chain. Although the IL-22 sequence shows only $22 \%$ homology with the sequence of IL-10, the protein structure of IL-22 is remarkably similar to that of IL-10 (2). IL-10, IL-22, IL-26, IL-28, and IL-29 share common usage of IL-10R $\beta$, while IL-10R $\alpha$ specifically binds to IL-10. Because IL-22R $\alpha$ is also used by IL-20, IL-22, and IL-24, it is difficult to draw conclusions about IL-22's function using knockout mice for its receptors.

The best-characterized cytokines of the IL-10 cytokine family are IL-10 and IL-22. IL-10 is regarded as the most important cytokine for suppressing pro-inflammatory responses in the immune system. IL-22 is believed to act exclusively on epithelial cells to promote cell regeneration and tissue repair. Particularly at the intestinal barrier, IL-10 and IL-22 play essential roles in the prevention or induction of mucosal damage and the development of colitis-associated cancer (CAC) $(3,4)$, which will be reviewed here as a major topic.

\section{OVERVIEW OF IL-10 AND IL-22}

IL-10 exerts its protective functions by regulating over-exuberant immune responses and autoimmune pathologies (5). Thirty years ago, Th2 cells were found to produce a factor that inhibited Th1 cell function (6); this factor was later named IL-10 (7). The human IL-10 gene, present on chromosome 1q32, is $4.7 \mathrm{~kb}$ long and includes 5 exons. The murine IL-10 locus spans $5.1 \mathrm{~kb}$ on chromosome $1 \mathrm{E} 4$. The sequence identity and transcription binding sites between human 
and murine IL-10 are conserved (8). IL-10 not only prevents cytokine production, but also the expression of chemokine (9) and co-stimulatory molecules (CD80, CD86, and MHC Class II) (10). IL-10 binds to IL- $10 \mathrm{R} \alpha$ and IL-10R $\beta$, which are commonly expressed on most immune cells. Therefore, IL-10 can regulate different innate and adaptive immune cells to evade the development of immune pathologies in different ways, such as inducing Treg and Tr1 cells or displaying an autocrine inhibitory effect on macrophages and dendritic cells (DCs) (11).

IL-22 was first identified by Renauld et al. in IL-9stimulated murine T cells (12). Murine IL-22 gene is localized on chromosome 10 while human IL-22 gene is located on chromosome 12q15, near the genes that encode for IFN- $\gamma$ and IL-26, other members of the IL-10 family (13). The IL-22 gene includes five exons and a $537 \mathrm{bp}$-long open reading frame that encodes for a 179 amino acid protein. Mouse and human IL22 share $79 \%$ homology (14). Because the IL-22 receptor is widely expressed on epithelial cells located at boundary tissues, such as gut, lung, liver, and skin, the major function of IL22 is to provide a protective response against pathogens at barrier surfaces $(15,16)$. The IL-22/IL-22R pathway has been shown to modulate the expression of many genes involved in tissue protection, survival, differentiation, and remodeling (17-19). Although IL-22 is mainly produced by the lymphoid lineage cells, including Th17 cells, $\gamma \delta \mathrm{T}$ cells, natural killer $\mathrm{T}$ cells, and innate lymphoid cells (ILCs), it has been reported that myeloid cells (macrophages and neutrophils) also produce IL-22 $(20,21)$.

IL-22 has two heterodimeric transmembrane receptors, IL22R1 and IL-10R2, which subsequently activate the JAK/STAT3, ERK, and JNK pathways (22). Similarly, IL-10 also drives its expression through the JAK-STAT signaling pathway (23) (Figure 1). On translocation to the nucleus, Stat dimer drives the transcription of Stat3-responsive genes, including SOCS-1 and SOCS-3 (24), thus mediating the anti-inflammatory activities of IL-10. IL-22-induced STAT3 activation in epithelial cells enhances their regeneration during tissue damage. Although STAT3 activation is responsible for most of the physiological responses of IL-10 and IL-22, both of them can activate STAT-1 and STAT- 5 under certain conditions $(2,25)$.

\section{REGULATION OF IL-10 AND IL-22 SECRETION BY MUCOSAL IMMUNE CELLS}

The intestinal flora, largely composed of resident bacteria, is most densely populated in the GI tract. Tolerance of the endogenous microbe is advantageous to the host while inappropriate immune responses are normally controlled by the innate and adaptive immune systems. IL-10 can be produced by various immune cells, including DCs, macrophages, mast cells, natural killer (NK)

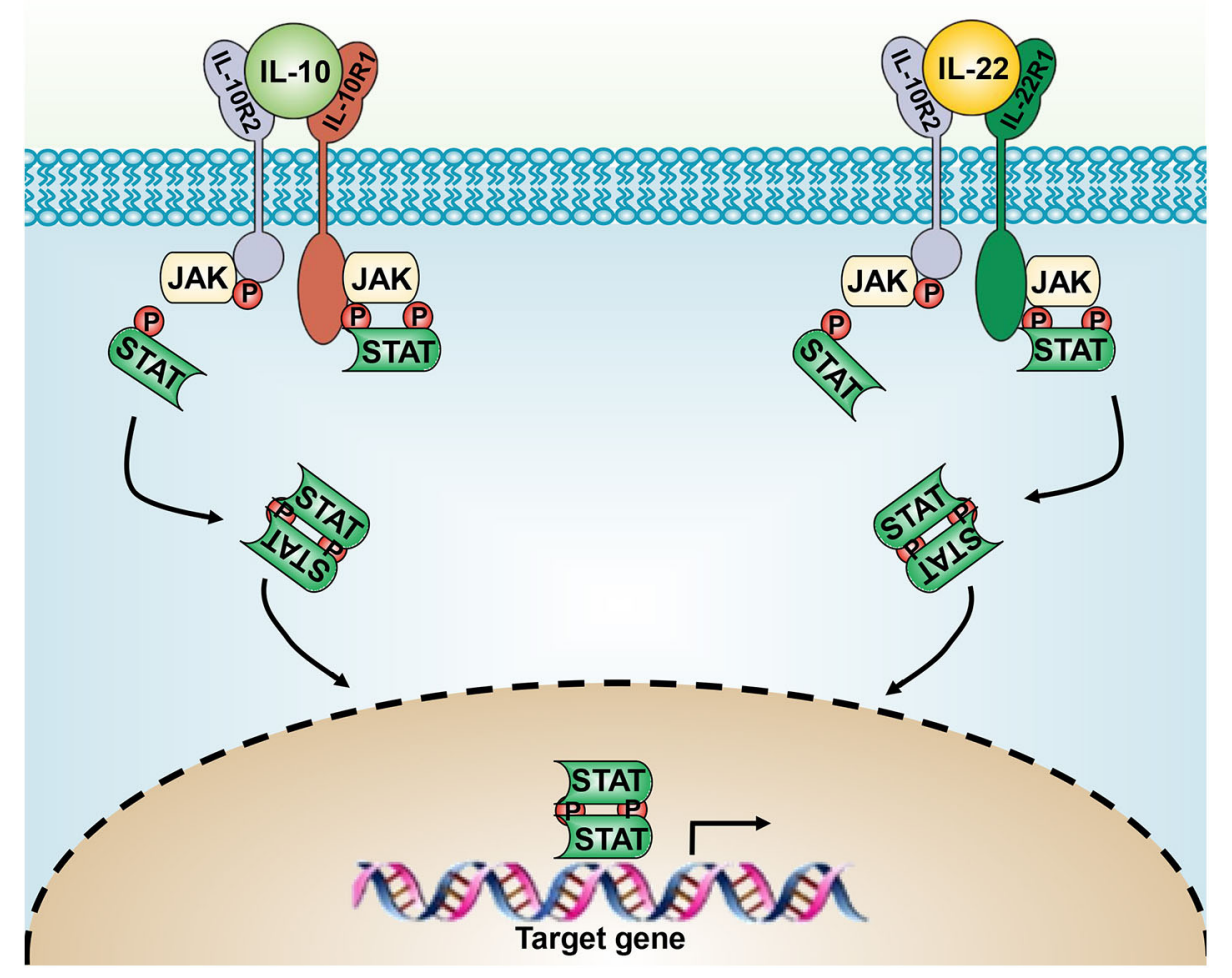

FIGURE 1 | The IL-10 and IL-22 signaling pathways. IL-10 and IL-20 signal through the heterodimeric receptor complexes IL-10R $\alpha / I L-10 R \beta$ and IL-22R $\alpha / I L-10 R \beta$, respectively. JAK/STAT-3 signaling leads to the expression of downstream genes. 
cells, eosinophils, neutrophils, $\mathrm{CD}^{+}{ }^{+}$and $\mathrm{CD} 8^{+} \mathrm{T}$ cells, and $\mathrm{B}$ cells $(5,26,27)$. IL-10 production was first described in Th2 cells (6), following with Th1, Th9, and Th17 cells were also shown to produce IL-10 (5). CD $4^{+}$Foxp $3^{+}$regulatory T cells and IL10-producing $\mathrm{T}(\mathrm{Tr}-1)$ cells have non-redundant functions in controlling intestinal inflammation $(26,28)$. In addition to $\mathrm{T}$ helper cells, macrophages, DCs, and neutrophils are also known to secrete IL-10 (29).

Several transcription factors, including Blimp-1, c-Maf, and GATA3, serve as potential regulators of IL-10 expression. Blimp$1^{-/-}$mice have been shown to develop a lethal multiorgan inflammatory disease caused by an accumulation of effector and memory T cells (30). Inactivation of c-MAF in the Treg cells has been found to result in dysfunction of IL-10 production and such mice were prone to spontaneous colitis (31). The transcription factor GATA3 has been described as a master regulator of IL-10 expression (32). In addition, CCAAT/enhancer binding protein$\beta$ (C/eBP $\beta$ ) (33) and NF- $\mathrm{B}$ p50 (34) are able to bind to the IL-10 promoter, activating IL-10 transcription in macrophages.

At the mucosal sites, IL-22 is mainly produced by the lymphoid lineage cells, including $\mathrm{CD}^{+}$and $\mathrm{CD} 8^{+} \mathrm{T}$ cells, $\gamma \delta$ $\mathrm{T}$ cells, NK cells, and ILCs $(35,36)$. Th1 cells were found as a source of IL-22, initially (37). Although Th17 cells can produce both IL-22 and IL-17, it is noteworthy that a distinct human $\mathrm{CD}^{+}{ }^{+} \mathrm{T}$ cell subset, known as Th22 cells, only produces IL-22 but not IL-17 $(17,38)$. Th22 cells produce their own cytokine profiles, such as IL-22, IL-26, and IL-33, which can be stimulated by IL-6, IL-21, and IL-23 (39); however, there is a debate about whether the Th22 cells are derived from Th17 cells. Apart from the adaptive cells, innate cells, including the ILCs and lymphoid tissue inducer (LTi) cells also serve as important sources of IL-22, particularly in the gastrointestinal tract (40). Th17 cells, type 3 innate lymphoid cells (ILC3s), and LTi cells express CCR6 and IL-23R (41). The Lymphotoxin (LT) pathway is only necessary for LTi cells but not for Nkp46 ${ }^{+}$ILC3s (42). Contrarily, loss in Ahr expression does not impact LTi cells formation and accumulation in the fetal intestine but influences the maintenance of gut ILC3s and Th22 cells $(43,44)$. Besides, IL22-producing neutrophils have been reported to crosstalk with colonic epithelial cells to upregulate the antimicrobial peptides, RegIII $\beta$ and S100A8 (21).

Numerous factors can regulate IL-22. IL-23 is believed to be a major inducer of IL-22 production due to the similar phenotype displayed by IL-23R $\alpha^{-/-}$mice and IL-22-/- mice (45). DCs and CX3CR1 ${ }^{+}$macrophages are potent sources of IL-23 $(46,47)$, as well as IL-1 $\beta$ (48). Constant IL- $1 \beta$ signaling is required for sustained IL-22 production (49). Although IL-7 does not directly induce IL-22, it can stabilize ROR $\gamma$ t expression in all IL-22-producing subsets (50). AhR is critical for ILC3derived IL-22 production, because $\mathrm{CD}^{+} \mathrm{T}$ cells from $\mathrm{AhR}^{-/-}$ mice develop Th17 cell responses, but fail to produce IL-22 (51). Notch signaling is also necessary for both $\mathrm{NCR}^{+}$and $\mathrm{NCR}^{-}$ ILC3 subsets to produce IL-22 (52). On the contrary, TGF- $\beta$ (53), ICOS (54), and IL-27 (55) have also been shown to prevent the production of IL-22. Lastly, IL-22BP is a natural inhibitor of IL-22, having more than a 20 -fold higher affinity for IL-22 than the cell surface receptor chain IL-22R1 (56), thus playing a pathogenic role in inflammatory bowel disease (IBD) (57) and multiple sclerosis (58) patients.

\section{IL-10 AND IL-22 IN MUCOSAL INFLAMMATION}

IL-10 and IL-22 target vastly diverse cell types and induce different downstream pathways. IL-10 prevents inflammatory responses by acting on Treg cells or macrophages, while IL22 directly promotes tissue epithelial cell regeneration and repair. In these ways, they maintain barrier integrity and reduce tissue damage.

\section{IL-10}

IL-10 is regarded as a major anti-inflammatory cytokine associated with many autoimmune diseases in humans and mice (2). IL-10 is highly relevant to IBD, as exhibited by the development of spontaneous enterocolitis in both IL-10 $1-$ and IL-10R $\beta^{-/-}$mice $(59,60)$. In humans, polymorphisms in IL-10 (61), IL- $10 \mathrm{R} \alpha$, and IL-10R $\beta$ (62) have been found to be correlated with very early-onset of colitis. Genome-wide association studies (GWAS) have further revealed an important role of the IL-10 axis in IBD pathogenesis (63). All the above data indicate that IL-10 signaling is important for maintaining gastrointestinal homeostasis. Interestingly, germ-free IL-10 ${ }^{-/-}$ mice do not develop colitis and the administration of antibiotics prevents colitis (64), indicating that the gut microbiota is necessary for the development of colitis. A single species, Helicobacter hepaticus, is responsible for this exacerbated disease (65). H. hepaticus-infected IL-10-/- mice display significantly increased production of IL-12 and IFN- $\gamma$, indicating that IL10 stimulation in response to intestinal flora is important for preventing IBD.

IL-10's protective function has been identified in many colitis models, including the DSS-induced colitis model and the CD45RB ${ }^{\text {hi }} \mathrm{T}$ cell transfer colitis model, which mimic ulcerative colitis (UC) and Crohn's disease, respectively (66). IL-10 inhibits IFN- $\gamma$ production by Th1 cells in mice reconstituted with CD45RB ${ }^{\text {hi }} \mathrm{CD}^{+} \mathrm{T}$ cells $(67)$ and reduces Th17 responses in the DSS model $(68,69)$. As microbiota is involved in the normal physiological status of the colon (70), the immunomodulatory effects of microbiota-produced short-chain fatty acids (SCFAs) have been examined. SCFAs not only promote IL-10 production by Th17 cells and reprogram their metabolic activity toward elevated glucose oxidation (71), but also induce antigenspecific IL-10 secretion by Th1 cells to maintain the intestinal homeostasis through G-protein coupled receptor 43 (72).

Because the IL-10R $\alpha$ receptor is widely expressed on $\mathrm{T}$ cells, B cells, macrophages, and DCs in the colon, identifying the specific immune cell lineage responding to IL-10 is important to understand IL-10's pivotal role in regulating colonic inflammation. Mice with Treg cells specifically lacking IL-10 or IL-10R $\alpha$ have been found to be prone to develop spontaneous colitis $(73,74)$, indicating that IL-10 enables Treg cells to suppress pathogenic Th17 cell responses in colitis (75), similar to the observation in mice with Treg-specific ablation of Stat3 
(76). By using conditional knockout mice with macrophages specifically lacking IL-10R $\alpha$, we found these highly activated macrophages could produce large amounts of IL-1 $\beta$ together with IL-6, promoting further Th17 cells development and colitis pathogenesis (77). We further identified IL-10 as a secreted inflammasome-tolerizing factor that could suppress caspase-1 activation and caspase-1-dependent maturation from pro-IL$1 \beta$ to IL-1 $\beta$ through regulation of caspase- 8 activation (78). Similarly, mice with CX3CR $1^{+}$macrophage-selective deletion of IL-10R $\alpha$ have been found to develop severe spontaneous colitis (79). In addition, macrophages in $\mathrm{Rag} 2^{-/-} \mathrm{IL}-10 \mathrm{R} \beta^{-/-}$mice showed impaired iTreg generation and Treg function. Since the shared usage of IL-10R $\beta$ by IL-10 and IL-22 is well-known (80), further studies need to investigate the separate role of these two cytokines. Clinically, the therapeutic effect of anti-TNF treatment in IBD patients is also dependent on the IL-10 signaling in macrophages (81). In the DSS-induced colitis model, IL-10 exerts its protective role through the macrophage-ROS-NO axis; lamina propria macrophages produce substantially greater levels of $\mathrm{NO}$ and ROS when they are unable to respond to IL-10 (82). IL$1 \beta$ mediates IBD in patients with IL-10 receptor deficiency was reported thereafter (83). Taken together, these studies prove that IL-10 signaling in the intestinal macrophages is indispensable for controlling mucosal inflammation.

It is well-proven that IL-10 is required for intestinal homeostasis; despite this, the downstream signaling pathways and the molecular basis involved have not been fully examined. Recently, several pathways related to IL-10 have been identified. Lp et al. revealed that IL-10 alters macrophage function by promoting the clearance of damaged mitochondria and modulating cellular metabolism in an STAT3-DDIT4-dependent manner $(84,85)$. Shp2 has been found to disrupt IL-10-induced STAT3 activation and its dependent anti-inflammatory response in human and murine macrophages (86). Inhibition of GSK3 $\beta$ results in tolerogenic bone marrow-derived DCs with profoundly decreased C/EBP $\beta$ and CREB DNA binding activities, which leads to a reduction of IL-10 and an increase in IL-12p70 production (87). This is consistent with another observation that GSK3 $\beta$ deletion in $\mathrm{CD}^{+} \mathrm{T}$ cells improves the survival of $\mathrm{T}$ cells and ameliorates colitis (88). In T cells, IL-10 can directly restrict the activation and function of $\mathrm{CD} 8^{+} \mathrm{T}$ cells by inducing the expression of Mgat5 and modifying the $\mathrm{N}$-glycan branching on surface glycoproteins (89). This mechanism is seen under inflammatory conditions as well; MGAT5 ${ }^{-1-}$ mice have been found to exhibit increased susceptibility to early-onset colitis, while reduced branched $\mathrm{N}$-glycosylation on mucosal $\mathrm{T}$ cells has been observed in case of UC patients (90). The involvement of IL-10 in this process needs to be further examined.

\section{IL-22}

Unlike IL-10, which targets hematopoietic cells, the major impact of IL-22 is on non-hematopoietic epithelial cells and stromal cells (4), due to the restricted IL-22R expression in these cells. IL-22 can promote proliferation and barrier function. Similar to IL-10, IL-22 exerts a protective effect on mucosal inflammation in most animal models, but plays a harmful role in the anti-CD40-induced colitis model, which will be discussed later in this section.

Elevated IL-22 levels have been detected in patients with Crohn's disease (91), as well as increased IL-22 and IL-22R $\alpha$ expressions in colon biopsy samples from UC patients (92). Also, in DSS-induced colitis, IL-22 has been shown to ameliorate the histological score (93) in an STAT3-dependent manner. Furthermore, STAT3 activation in epithelial cells is dependent on IL-22 rather than IL-6 (94), suggesting that targeting the STAT3 signaling pathway in intestinal epithelial cells (IECs) is a promising therapeutic approach for IBD patients (95). Initially, it was believed that IL-22-expressing NK cells are responsible for protection against intestinal injury (96). Later, these cells were identified to display a "CD3 ${ }^{-} \mathrm{CD} 127^{+} \mathrm{CD} 56^{+} \mathrm{NKp} 44^{+}$" phenotype (97) and were named as ILC3s (98). ILCs are innate immune cells that lack antigen specificity, enriched at mucosal surfaces, and regulate immune responses as well as tissue homeostasis (98-101). ILCs can be divided into subsets that are characterized by their production of cytokines, including ILC1 (IFN- $\gamma$ ) (102), ILC2 (IL-5/IL-13), ILC3 (IL-17/IL-22), and ILCreg (IL-10/TGF- $\beta$ ) (103).

IL-22-producing ILC3s have been shown to play a protective role in a mouse model of infectious colitis induced by Citrobacter rodentium. These ROR $\gamma \mathrm{t}^{+} \mathrm{NKp} 46^{+}$ILC3s, but not $\mathrm{NCR}^{-}$ILC3s, are regulated by an intrinsic TCF-1 pathway that plays a critical role in the host defense against $C$. rodentium infection (104). Notably, Giacomin et al. found that $\operatorname{IKK} \alpha^{\Delta \mathrm{IEC}}$ mice displayed impaired IL-22 production by ROR $\gamma \mathrm{t}^{+}$ILC3s, while rIL-22 administration or transferring WT cells protected $\mathrm{IKK} \alpha^{\Delta \mathrm{IEC}}$ mice from C. rodentium-induced morbidity (105). Lamina propria $\mathrm{CX}_{3} \mathrm{CR}^{+}$mononuclear phagocytes are stronger inducers of ILC3 production of IL-22 (106).

With respect to $\mathrm{T}$ cell-induced colitis, no significant difference has been reported between $\mathrm{RAGl}^{-/-}$mice that received $\mathrm{CD}_{5} \mathrm{RB}^{\text {high }} \mathrm{IL}^{2} 22^{+/+}$or $\mathrm{CD} 45 \mathrm{RB}^{\text {high }} \mathrm{IL}-22^{-/-} \mathrm{CD} 4^{+} \mathrm{T}$ cells, indicating that the mice rely on a host-derived source of IL22 during IBD development (96). Upon CD45RB ${ }^{\text {hi }} \mathrm{T}$ cell transfer, the disease severity in $\mathrm{Ragl}^{-/-} \mathrm{Ahr^{-/- }}$ mice has been found to be substantially higher than that in $\mathrm{Ragl}^{-/-}$mice. Ahr-l- mice with reduced ILC3-produced IL-22 are prone to spontaneous colitis accompanied with increased segmented filamentous bacteria and Th17 cells (107). Interestingly, TNFlike ligand $1 \mathrm{~A}$ (TL1A) and death receptor 3 (DR3) are a ligand-receptor pair involved in the pathogenesis of IBD. TL1A potently enhances IL-23- and IL- $1 \beta$-induced production of IL22 and GM-CSF by ILC3 $(106,108)$. Together with $\alpha$-DR3 treatment, it causes a reduction in the ILC3 numbers in the large intestine (109).

Although widely considered as an anti-inflammatory cytokine, IL-22 plays a pathogenic role in the innate colitis model. ILC3s have been identified as the only mediator for disease induction in the anti-CD40-induced colitis model (110). Adoptively transferring $\mathrm{CD}_{4} 5^{+} \mathrm{Lin}^{-} \mathrm{Thy}^{+} \mathrm{CD} 127^{+} \mathrm{NKp} 46^{+}$ ILC3s from $\mathrm{Rag}^{-/-}$mice into NSG mice has been shown to cause severe colitis, proving that $\mathrm{NKp} 46^{+}$ILC3s alone are sufficient to induce innate immune colitis (111). Neutralization of IL-22 results in a significant reduction in the weight loss 
and colitis scores caused by the anti-CD40 injection (111), while IL-22 administration has been shown to drive more severe mucosal damage (112). Identical results were reported in another CD45RB ${ }^{\text {lo }}$ memory $\mathrm{T}$ cell transfer colitis model (113). Interestingly, transferred Treg cells reduce the ILC3 production of IL-22 through suppression of the CX3CR $1^{+}$macrophage production of IL-23 and IL-1 $\beta$ (114), indicating a potential network between adaptive and innate immune responses.

Together, such conflicting reports on the role of IL-22 in different colitis models reflect the complex function of ILC3 in relation to gut inflammation. Since it is unclear why ILC3induced IL-22 functions as a double-edged sword and displays both pro-inflammatory and anti-inflammatory properties in maintaining gut homeostasis, particularly in case of innate cellinduced inflammation, more extensive studies are required in the future to unravel its mechanism of action.

\section{IL-10 AND IL-22 IN COLORECTAL CANCER \\ IL-10}

IL-10 has a paradoxical role in cancer development (115). IL-10 and TGF- $\beta$ are considered as the two most important immunosuppressive cytokines in the immune system as they can help tumors escape immune surveillance in the tumor microenvironment. Clinical analysis shows poor prognosis of melanoma patients with high levels of IL-10 in the serum (116) and tumor tissue (117). Mechanistically, IL-10 not only inhibits MHC class II expression on APCs, but also reduces the cytotoxicity of NK cells and $\mathrm{CD}^{+}{ }^{+} \mathrm{T}$ cells (3). Notably, while IL- $10^{+}$Treg cells promote tumor growth and induce $\mathrm{T}$ cell exhaustion, deletion of IL-10 in Treg cells has been shown to cause a drastic reduction in the expression of PD-1, TIM3, and LAG3 in intra-tumoral CD8 ${ }^{+} \mathrm{T}$ cells (118).

Chronic inflammation is one of the hallmarks of cancer. In the setting of intestinal inflammation, the mucosal immune response leads to colorectal cancer, as exhibited by the increased incidence of colitis-associated colon cancers in IBD patients. Sixty percent $\mathrm{IL}-10^{-/}$mice develop colorectal cancer; these mice have significantly increased levels of pro-inflammatory cytokines (IFN- $\gamma$, TNF- $\alpha$, IL-1 $\beta$, and IL-6), indicating the chronic intestinal inflammation related with the tumor growth $(119,120)$. It is interesting to note that apart from COX2 (121) and PTEN (122), which have been found to facilitate the progression of cancer in IL-10 $0^{-/-}$mice, the development of colitis also depends on IL-22, as exhibited by the elevated levels of IL-22+ Th17 cells in the colon of IL- $10^{-/-}$mice (123).

In fact, elevated levels of peripheral Th17 cells and serum Th17-related cytokines have been reported in patients with colorectal cancer (124) while a "Th17 expression signature" has been observed in early colorectal cancer (125). It is wellknown that IL- $1 \beta$ and IL- 6 together with TGF- $\beta$ can induce differentiation and development of Th17 cells $(126,127)$. Coincidently, IL- $1 \beta$ and IL- 6 also participate in colorectal cancer. Mice deficient in the IL-1 receptor-related molecule SIGIRR show increased tumor growth (128), while tumor-infiltrating myeloid cells produce high levels of IL- $1 \beta$ and IL- 6 that promote tumorigenesis $(129,130)$. IL-6 secreted by lamina propria myeloid cells not only protects IECs from apoptosis but also provides the survival signal for premalignant IECs via the STAT3 pathway (131). Furthermore, treatment with anti-IL-6 in IBD patients has been shown to prevent the onset of CAC $(132,133)$. Although it is clear that macrophages lacking IL-10 signaling lead to increased development of Th17 cells in severe colitis $(77,79)$, the molecular mechanisms underlying the complex functions of IL-10 in cancer immune surveillance under inflammatory conditions still remain elusive.

\section{IL-22}

The role of IL-22 in cancer is also complicated. In a healthy condition, IL-22 cannot initiate tumor formation by itself and maintains barrier integrity against cancer development; but under inflammatory conditions, IL-22 directly promotes tumor growth or induces "stemness-like" cancer cells via STAT3dependent signaling.

In a study on AOM/DSS-induced colorectal cancer, the number and size of tumors were found to increase in IL-22 $2^{-/-}$ mice compared to WT mice, while the IL-22 $\mathrm{BP}^{-/-}$mice were found to exhibit increased tumorigenesis in an NLRP3/NLRP6IL-18-dependent manner (134), indicating that IL-22 can protect mice against tumor development. Conversely, data also shows that IL-22 results in tumor progression $(135,136)$. With the elevated IL-17 and IL-22 levels in STAT1 ${ }^{-/-}$mice, the colonic epithelial cell proliferation increases while the tumor apoptosis rate decreases in the early stage of tumor formation (137). In humans, an SNP variation in the human IL-22 gene greatly increases the risk of colon cancer (138). Th22 and IL-22 levels have also been reported to be profoundly increased in CRC patients (139). Moreover, in Helicobacter pylori/AOMinduced CRC models, Kirchberger et al. reported accumulation of Nkp46 ${ }^{-} \mathrm{CD}^{-}{ }^{-} \mathrm{lin}^{-} \mathrm{Thy} 1^{\mathrm{hi}}$ ILCs at tumor sites. These ILCs produce IL-22 that promotes cancer development by inducing epithelial cell proliferation through phosphorylation of the Stat3 pathway; neutralization of IL-22 leads to abrogation of this process (140).

STAT3 is oncogenic in colorectal cancer, as evidenced by the observation that mice with specific ablation of STAT3 in IECs develop fewer tumors in colorectal cancer $(131,141)$. Similarly, overexpression of IL-10R $\beta$ in HT29 promotes IL22/STAT3 signaling in colorectal carcinogenesis (142). Notably, STAT3 can be activated by IL-6, IL-10, IL-11 as well as IL-22 (141). Although the IL-22-STAT3 pathway remains very important for epithelial cell proliferation and CAC development, IL-6- (143) and IL-11(144) mediated gp130-STAT3 pathway is also required for GI cancer progression.

STAT3 signaling is required not only by the epithelial cells in the tumor microenvironment but also by cancer stem cells. For example, in human colorectal cancer tissues, $\mathrm{CCR} 6{ }^{+} \mathrm{CD} 4^{+}$ $\mathrm{T}$ cells have been shown to be responsible for the secretion of the entire amount of IL-22 (145). IL-22 activates the STAT3 phosphorylation cascade in cancer cells and induces the expression of stem cell markers (SOX2, NANOG, and POU5F1), resulting in increased cancer stemness and tumorigenic potential (146). In line with this, ILC3s also maintain intestinal epithelial stem cells after tissue damage. LGR5 (Leucine-rich repeat 
containing $\mathrm{G}$ protein-coupled receptor) is known to be a stem cell marker in the murine small intestine and colon (147). By using ILC3-deficient Lgr5 reporter mice, Aparicio-Domingo et al. and Lindemans et al. showed that in the absence of ILC3s or IL-22, intestinal stem cells become severely impaired after tissue damage (148), in an STAT3-dependent mechanism (149).

Finally, IL-22 has been shown to directly promote tumor growth by inducing proliferation and exhibiting anti-apoptotic effects on tumor cells in the colon (150) and lung (151). Tumor cells have been found to display a high level of IL-22 receptor expression as well as increased IL-22 production by surrounding tumor infiltrating $\mathrm{T}$ cells, indicating that IL-22 promotes tumor proliferation by engaging the STAT3 signaling in tumor tissues. In the AOM/Helicobacter hepaticus-induced colorectal cancer model, repair mechanisms for DNA damage potentially lead to the accumulation of mutations. IL-22-driven, iNOS-dependent DNA damage is associated with inflammation and cancer (152).

The diverse roles of IL-22 in cancer immunity are still not clear. It is possible that the generation of IL-22 in different stages of cancer development leads to different consequences. As a potential therapeutic target, more fundamental studies on IL-22 need to be investigated.

\section{THERAPEUTIC POTENTIAL FOR IL-10 AND IL-22 IN INTESTINAL DISEASES}

Based on the fact that mice deficient in either IL-10 or the IL-10 receptor $\alpha$ or $\beta$ chains develop spontaneous colitis and multiple anti-inflammatory functions in $\operatorname{IBD}(60,119)$, after proving recombinant IL-10 is safe for human in clinical trial at early $1990 \mathrm{~s}$ (153), rhuIL-10 was used to treat IBD patients in clinical trial in 2000. In this double-blinded clinical study, IL-10 treatment group shows no significant difference (154). Another clinical study using rhuIL-10 for testing its prevention role for patients with relapse also displays no significant benefit from IL-10 treatment (155). Moreover, increased IFN- $\gamma$ production (156) and reduced hemoglobin and thrombocyte counts (157) are seen in patients, suggesting a more complex immune function of IL-10 in IBD. It is possible that relative low concentration of delivered rhuIL-10 in the inflamed tissues. To overcome this difficulty, PEGylated IL-10 or IL-10-Fc fusion proteins are designed, respectively (158, 159). Smartly, local delivery of IL-10 by engineered bacterial strains, such as Lactobacilli and bifidobacterial, have been created to specifically increase IL-10 concentration in the colon (160, 161). Lactobacilli and bifidobacterial are probiotics which have no apparent capacity to induce mucosal inflammation, preliminary trials about IL-10-engineered probiotics in human IBD patients should be encouraged (162). On the other hand, intravenous IL10 administration displays no organ specificity (163), it prevents both mucosal and systemic host responses. Therefore, a xyloseinducible expression system (164) has been used to control Lactobacilli's IL-10 production, it leads to a high-level and longterm IL-10 production, which is efficiently delivered to mucosal surfaces (165). Interestingly, the employment of fermented milks as a new form of administration of IL-10-producing Lactobacilli is effective in the prevention of mucosal inflammation (166).
Despite it, IL-10/IL-10R complex is still an attractive target for cancer immune therapy. Mice treated with $\mathrm{CpG}$ plus anti-IL$10 \mathrm{R} \alpha$ have dramatically reduced C26 colon carcinoma growth, while anti-IL-10R or CpG alone does not, indicating blockade IL10 signaling pathway together with TLR-9 stimulation promotes tumor rejection (167). Recently, PEGylated IL-10 is shown to Induce systemic immune activation, including intra-tumoral $\mathrm{CD}^{+} \mathrm{T}$ cells proliferation and expansion, combined PEGylated IL-10 with anti-PD-1 Ab increased the expansion of LAG-3 ${ }^{+}$ PD- $1^{+} \mathrm{CD}^{+} \mathrm{T}$ cells (168). This result indicates IL-10 can synergize with anti-PD-1 Ab to reverse the dysfunction status of $\mathrm{T}$ cells and eliminate the tumor cells. Whether the similar mechanism appears in colorectal cancer need to be explored. Due to the strong immune suppressive functions, IL-10 can repress cytotoxic T cells activation and IL-12 production. But inflammation may promote tissue damage and oncogenesis (169, 170 ), especially in colorectal cancer. Thereby, IL-10 may inhibit the increased risk of intestinal oncogenesis. The failures of administration of IL-10 in IBD patients stop the step for further treating colorectal cancer patients with IL-10. More knowledge about how inflammation or tissue specific tolerance for tumor proliferation will be helpful to determine using recombinant IL-10 or anti-IL-10R Ab to fight against cancer.

IL-22 plays an essential role in regulating intestinal equilibrium during inflammation. IL-22 not only promotes epithelial cells activation though STAT3 signaling pathway, but also induces various antimicrobial peptides (Claudin-2, and Fut-2) (171), as well as enhances innate intestinal defense functions. IL-22 exerting a beneficial role in various murine colitis models is well-defined (3). As we discussed above, only in some ILC3 cells involved colitis models, such as anti-CD40 and $\mathrm{CD} 45 \mathrm{RBl}^{\text {low }}$ transferred colitis models, IL-22 plays a pathogenic role $(111,113)$. Now, IL-22 based clinical trials have been investigated. A recombinant fusion protein, F652, is consisting of two human IL-22 molecules linked to an immunoglobulin constant region $\left(\mathrm{IgG}_{2}-\mathrm{Fc}\right)$. F652 was evaluated in a randomized, double-blind, placebo-controlled study. Administration of this hIL-22 dimer to healthy male volunteers is safe and well-tolerated (172). Another hIL-22 IgG fusion protein, UTTR1147A, was assessed in healthy mice, rats and cynomolgus monkeys. Moreover, UTTR1147A is shown to induce STAT3 activation in primary human hepatocytes and human colon cell lines (173). A clinical trial (NCT02847052) for studying the role of IL-22BP in IBD patients is completed, although the results are not available yet. Further clinical trials of F-652 and UTR1147A should be planed for treating inflammatory bowel diseases. Finally, as myeloid cells have higher IL-10 receptor expression while the extensive expression of IL-22R on epithelial cells, a way to induce specific cell lineage responding to these cytokines should be concerned for the future therapeutic method.

\section{CONCLUDING REMARKS}

IL-10 and IL-22 are tightly associated with the prevention of mucosal inflammation and have a variety of functions in colorectal cancer development. 
IL-10 is necessary for controlling the abnormal immune response against harmful microorganisms and the consequent intestinal damage. The dynamic interactions between IL-10 and the different IL-10 responsive immune cell lineages participate in the pathogenesis of IBD. Apart from Treg cells, macrophages are considered as another major immune subset to respond to IL-10 in the gastrointestinal tract. IL-22 is believed to act exclusively on epithelial cells to promote proliferation and barrier function in the intestine and, therefore, plays a protective role in IBD.

IL-10 leads to tumor growth and promotion, but it also contributes to the eradication and suppression of cancer development under colonic inflammatory conditions. IL-22 is also a controversial cytokine in tumor development; the IL-22-STAT3 axis induces anti-apoptotic genes and provides survival and proliferation signals for both normal and malignant

\section{REFERENCES}

1. Pestka S, Krause CD, Sarkar D, Walter MR, Shi YF, Fisher PB. Interleukin-10 and related cytokines and receptors. Annu Rev Immunol. (2004) 22:92979. doi: 10.1146/annurev.immunol.22.012703.104622

2. Ouyang WJ, Rutz S, Crellin NK, Valdez PA, Hymowitz SG. Regulation and functions of the IL-10 family of cytokines in inflammation and disease. Annu Rev Immunol. (2011) 29:71-109. doi: 10.1146/annurev-immunol-031210-101312

3. Ouyang W, O'Garra A. IL-10 family cytokines IL-10 and IL-22: from basic science to clinical translation. Immunity. (2019) 50:87191. doi: 10.1016/j.immuni.2019.03.020

4. Gao B, Xiang X. Interleukin-22 from bench to bedside: a promising drug for epithelial repair. Cell Mol Immunol. (2019) 16:666-7. doi: 10.1038/s41423-018-0055-6

5. Saraiva M, O'Garra A. The regulation of IL-10 production by immune cells. Nat Rev Immunol. (2010) 10:170-81. doi: 10.1038/nri2711

6. Fiorentino DF, Bond MW, Mosmann TR. Two types of mouse T helper cell. IV. Th2 clones secrete a factor that inhibits cytokine production by Th1 clones. J Exp Med. (1989) 170:2081-95. doi: 10.1084/jem.170.6.2081

7. Moore KW, Vieira P, Fiorentino DF, Trounstine ML, Khan TA, Mosmann TR. Homology of cytokine synthesis inhibitory factor (IL-10) to the Epstein-Barr virus gene BCRFI. Science. (1990) 248:1230-4. doi: 10.1126/science. 2161559

8. Iyer SS, Cheng G. Role of interleukin 10 transcriptional regulation in inflammation and autoimmune disease. Crit Rev Immunol. (2012) 32:2363. doi: 10.1615/CritRevImmunol.v32.i1.30

9. Kasama T, Strieter RM, Lukacs NW, Burdick MD, Kunkel SL. Regulation of neutrophil-derived chemokine expression by IL-10. J Immunol. (1994) 152:3559-69.

10. Willems F, Marchant A, Delville JP, Gerard C, Delvaux A, Velu T, et al. Interleukin-10 inhibits B7 and intercellular adhesion molecule1 expression on human monocytes. Eur J Immunol. (1994) 24:10079. doi: 10.1002/eji.1830240435

11. Wei $\mathrm{H}$, Li B, Sun A, Guo F. Interleukin-10 family cytokines immunobiology and structure. Adv Exp Med Biol. (2019) 1172:79-96. doi: 10.1007/978-981-13-9367-9_4

12. Dumoutier L, Louahed J, Renauld JC. Cloning and characterization of IL-10-related $\mathrm{T}$ cell-derived inducible factor (IL-TIF), a novel cytokine structurally related to IL-10 and inducible by IL-9. J Immunol. (2000) 164:1814-9. doi: 10.4049/jimmunol.164.4.1814

13. Dumoutier L, Van Roost E, Ameye G, Michaux L, Renauld JC. IL-TIF/IL-22: genomic organization and mapping of the human and mouse genes. Genes Immun. (2000) 1:488-94. doi: 10.1038/sj.gene.6363716

14. Dumoutier L, Van Roost E, Colau D, Renauld JC. Human interleukin-10related $\mathrm{T}$ cell-derived inducible factor: molecular cloning and functional cells. Therefore, in the healthy condition, it prevents tumor formation; however, once a tumor has been established, IL-22 promotes tumorigenesis.

\section{AUTHOR CONTRIBUTIONS}

$\mathrm{H}-\mathrm{XW}$ wrote the manuscript. BW and BL provided the guidance and revised the manuscript. All authors contributed to the article and approved the submitted version.

\section{FUNDING}

This work was supported by the National Natural Science Foundation of China (Grant No. 81974258). characterization as an hepatocyte-stimulating factor. Proc Natl Acad Sci USA. (2000) 97:10144-9. doi: 10.1073/pnas.170291697

15. Sonnenberg GF, Fouser LA, Artis D. Border patrol: regulation of immunity, inflammation and tissue homeostasis at barrier surfaces by IL-22. Nat Immunol. (2011) 12:383-90. doi: 10.1038/ni.2025

16. Niess JH, Hruz P, Kaymak T. The interleukin-20 cytokines in intestinal diseases. Front Immunol. (2018) 9:1373. doi: 10.3389/fimmu.2018.01373

17. Eyerich S, Eyerich K, Pennino D, Carbone T, Nasorri F, Pallotta S, et al. Th22 cells represent a distinct human $\mathrm{T}$ cell subset involved in epidermal immunity and remodeling. J Clin Invest. (2009) 119:357385. doi: 10.1172/JCI40202

18. Dudakov JA, Hanash AM, van den Brink MR. Interleukin22: immunobiology and pathology. Annu Rev Immunol. (2015) 33:747-85. doi: 10.1146/annurev-immunol-032414-112123

19. Colonna M, Interleukin-22-producing natural killer cells and lymphoid tissue inducer-like cells in mucosal immunity. Immunity. (2009) 31:1523. doi: 10.1016/j.immuni.2009.06.008

20. Hansson M, Silverpil E, Linden A, Glader P. Interleukin-22 produced by alveolar macrophages during activation of the innate immune response. Inflamm Res. (2013) 62:561-9. doi: 10.1007/s00011-013-0608-1

21. Zindl CL, Lai JF, Lee YK, Maynard CL, Harbour SN, Ouyang W, et al. IL22-producing neutrophils contribute to antimicrobial defense and restitution of colonic epithelial integrity during colitis. Proc Natl Acad Sci USA. (2013) 110:12768-73. doi: 10.1073/pnas.1300318110

22. Lejeune D, Dumoutier L, Constantinescu S, Kruijer W, Schuringa JJ, Renauld JC. Interleukin-22 (IL-22) activates the JAK/STAT, ERK, JNK, and p38 MAP kinase pathways in a rat hepatoma cell line. Pathways that are shared with and distinct from IL-10. J Biol Chem. (2002) 277:3367682. doi: 10.1074/jbc.M204204200

23. Benkhart EM, Siedlar M, Wedel A, Werner T, Ziegler-Heitbrock HW. Role of Stat 3 in lipopolysaccharide-induced IL-10 gene expression. J Immunol. (2000) 165:1612-7. doi: 10.4049/jimmunol.165.3.1612

24. Ding Y, Chen D, Tarcsafalvi A, Su R, Qin L, Bromberg JS. Suppressor of cytokine signaling 1 inhibits IL-10-mediated immune responses. J Immunol. (2003) 170:1383-91. doi: 10.4049/jimmunol.170.3.1383

25. Wolk K, Kunz S, Witte E, Friedrich M, Asadullah K, Sabat R. IL22 increases the innate immunity of tissues. Immunity. (2004) 21:24154. doi: 10.1016/j.immuni.2004.07.007

26. Barnes MJ, Powrie F. Regulatory T cells reinforce intestinal homeostasis. Immunity. (2009) 31:401-11. doi: 10.1016/j.immuni.2009.08.011

27. Sun H, Sun C, Xiao W, Sun R. Tissue-resident lymphocytes: from adaptive to innate immunity. Cell Mol Immunol. (2019) 16:205-15. doi: 10.1038/s41423-018-0192-y

28. Ma H, Tao $\mathrm{W}$, Zhu S. $\mathrm{T}$ lymphocytes in the intestinal mucosa: defense and tolerance. Cell Mol Immunol. (2019) 16:216-24. doi: 10.1038/s41423-019-0208-2 
29. Comi M, Avancini D, Santoni de Sio F, Villa M, Uyeda MJ, Floris M, et al. Coexpression of CD163 and CD141 identifies human circulating IL10-producing dendritic cells (DC-10). Cell Mol Immunol. (2020) 17:95107. doi: 10.1038/s41423-019-0218-0

30. Kallies A, Hawkins ED, Belz GT, Metcalf D, Hommel M, Corcoran LM, et al. Transcriptional repressor Blimp-1 is essential for $\mathrm{T}$ cell homeostasis and self-tolerance. Nat Immunol. (2006) 7:466-74. doi: 10.1038/ni1321

31. Xu M, Pokrovskii M, Ding Y, Yi R, Au C, Harrison OJ, et al. c-MAFdependent regulatory $\mathrm{T}$ cells mediate immunological tolerance to a gut pathobiont. Nature. (2018) 554:373-7. doi: 10.1038/nature25500

32. Shoemaker J, Saraiva M, O'Garra A. GATA-3 directly remodels the IL-10 locus independently of IL-4 in CD4 ${ }^{+}$T cells. J Immunol. (2006) 176:34709. doi: 10.4049/jimmunol.176.6.3470

33. Liu YW, Tseng HP, Chen LC, Chen BK, Chang WC. Functional cooperation of simian virus 40 promoter factor 1 and CCAAT/enhancerbinding protein beta and delta in lipopolysaccharide-induced gene activation of IL-10 in mouse macrophages. J Immunol. (2003) 171:8218. doi: 10.4049/jimmunol.171.2.821

34. Cao S, Zhang X, Edwards JP, Mosser DM. NF-kappaB1 (p50) homodimers differentially regulate pro- and anti-inflammatory cytokines in macrophages. J Biol Chem. (2006) 281:26041-50. doi: 10.1074/jbc.M602222200

35. Rutz S, Eidenschenk C, Ouyang W. IL-22, not simply a Th17 cytokine. Immunol Rev. (2013) 252:116-32. doi: 10.1111/imr.12027

36. Seillet $\mathrm{C}$, Jacquelot $\mathrm{N}$. Sensing of physiological regulators by innate lymphoid cells. Cell Mol Immunol. (2019) 16:442-51. doi: 10.1038/s41423-019-0217-1

37. Wolk K, Kunz S, Asadullah K, Sabat R. Cutting edge: immune cells as sources and targets of the IL-10 family members? J Immunol. (2002) 168:5397402. doi: 10.4049/jimmunol.168.11.5397

38. Duhen T, Geiger R, Jarrossay D, Lanzavecchia A, Sallusto F. Production of interleukin 22 but not interleukin 17 by a subset of human skin-homing memory T cells. Nat Immunol. (2009) 10:857-63. doi: 10.1038/ni.1767

39. Cui G. TH9, TH17, and TH22 cell subsets and their main cytokine products in the pathogenesis of colorectal cancer. Front Oncol. (2019) 9:1002. doi: 10.3389/fonc.2019.01002

40. Kansler ER, Li MO. Innate lymphocytes-lineage, localization and timing of differentiation. Cell Mol Immunol. (2019) 16:627-33. doi: 10.1038/s41423-019-0211-7

41. Rutz S, Wang X, Ouyang W. The IL-20 subfamily of cytokines-from host defence to tissue homeostasis. Nat Rev Immunol. (2014) 14:78395. doi: $10.1038 /$ nri3766

42. Sonnenberg GF, Monticelli LA, Elloso MM, Fouser LA, Artis D. CD4(+) lymphoid tissue-inducer cells promote innate immunity in the gut. Immunity. (2011) 34:122-34. doi: 10.1016/j.immuni.2010.12.009

43. Qiu J, Heller JJ, Guo X, Chen ZM, Fish K, Fu YX, et al. The aryl hydrocarbon receptor regulates gut immunity through modulation of innate lymphoid cells. Immunity. (2012) 36:92-104. doi: 10.1016/j.immuni.2011.11.011

44. Van Kaer L, Postoak JL, Wang C, Yang G, Wu L. Innate, innate-like and adaptive lymphocytes in the pathogenesis of MS and EAE. Cell Mol Immunol. (2019) 16:531-9. doi: 10.1038/s41423-019-0221-5

45. Zheng Y, Danilenko DM, Valdez P, Kasman I, Eastham-Anderson $\mathrm{J}$, Wu J, et al. Interleukin-22, a $\mathrm{T}(\mathrm{H}) 17$ cytokine, mediates IL-23induced dermal inflammation and acanthosis. Nature. (2007) 445:64851. doi: $10.1038 /$ nature 05505

46. Kinnebrew MA, Buffie CG, Diehl GE, Zenewicz LA, Leiner I, Hohl $\mathrm{TM}$, et al. Interleukin 23 production by intestinal CD103(+)CD11b $(+)$ dendritic cells in response to bacterial flagellin enhances mucosal innate immune defense. Immunity. (2012) 36:276-87. doi: 10.1016/j.immuni.2011. 12.011

47. Manta C, Heupel E, Radulovic K, Rossini V, Garbi N, Riedel CU, et al. $\mathrm{CX}(3) \mathrm{CR} 1(+)$ macrophages support IL-22 production by innate lymphoid cells during infection with Citrobacter rodentium. Mucosal Immunol. (2013) 6:177-88. doi: 10.1038/mi.2012.61

48. Sims JE, Smith DE. The IL-1 family: regulators of immunity. Nat Rev Immunol. (2010) 10:89-102. doi: 10.1038/nri2691

49. Hughes T, Becknell B, Freud AG, McClory S, Briercheck E, Yu J, et al. Interleukin-1beta selectively expands and sustains interleukin$22+$ immature human natural killer cells in secondary lymphoid tissue. Immunity. (2010) 32:803-14. doi: 10.1016/j.immuni.2010.06.007
50. Vonarbourg C, Mortha A, Bui VL, Hernandez PP, Kiss EA, Hoyler $\mathrm{T}$, et al. Regulated expression of nuclear receptor RORgammat confers distinct functional fates to NK cell receptorexpressing RORgammat(+) innate lymphocytes. Immunity. (2010) 33:736-51. doi: 10.1016/j.immuni.2010.10.017

51. Veldhoen M, Hirota K, Westendorf AM, Buer J, Dumoutier L, Renauld JC, et al. The aryl hydrocarbon receptor links TH17-cellmediated autoimmunity to environmental toxins. Nature. (2008) 453:106-9. doi: 10.1038/nature06881

52. Possot C, Schmutz S, Chea S, Boucontet L, Louise A, Cumano A, et al. Notch signaling is necessary for adult, but not fetal, development of RORgammat(+) innate lymphoid cells. Nat Immunol. (2011) 12:94958. doi: 10.1038/ni.2105

53. Rutz S, Noubade R, Eidenschenk C, Ota N, Zeng W, Zheng Y, et al. Transcription factor c-Maf mediates the TGF-beta-dependent suppression of IL-22 production in T(H)17 cells. Nat Immunol. (2011) 12:123845. doi: 10.1038/ni.2134

54. Paulos CM, Carpenito C, Plesa G, Suhoski MM, Varela-Rohena A, Golovina TN, et al. The inducible costimulator (ICOS) is critical for the development of human T(H)17 cells. Sci Transl Med. (2010) 2:55ra78. doi: 10.1126/scitranslmed.3000448

55. Wang H, Li Z, Yang B, Yu S, Wu C. IL-27 suppresses the production of IL-22 in human $\mathrm{CD} 4(+) \mathrm{T}$ cells by inducing the expression of SOCS1. Immunol Lett. (2013) 152:96-103. doi: 10.1016/j.imlet.2013.05.001

56. Jones BC, Logsdon NJ, Walter MR. Structure of IL-22 bound to its high-affinity IL-22R1 chain. Structure. (2008) 16:133344. doi: 10.1016/j.str.2008.06.005

57. Pelczar P, Witkowski M, Perez LG, Kempski J, Hammel AG, Brockmann L, et al. A pathogenic role for T cell-derived IL-22BP in inflammatory bowel disease. Science. (2016) 354:358-62. doi: 10.1126/science.aah5903

58. Lindahl $H$, Guerreiro-Cacais AO, Bedri SK, Linnerbauer $M$, Linden $\mathrm{M}$, Abdelmagid $\mathrm{N}$, et al. IL-22 binding protein promotes the disease process in multiple sclerosis. J Immunol. (2019) 203:888-98. doi: 10.4049/jimmunol.1900400

59. Kuhn R, Lohler J, Rennick D, Rajewsky K, Muller W. Interleukin10-deficient mice develop chronic enterocolitis. Cell. (1993) 75:26374. doi: 10.1016/0092-8674(93)80068-P

60. Spencer SD, Di Marco F, Hooley J, Pitts-Meek S, Bauer M, Ryan AM, et al. The orphan receptor CRF2-4 is an essential subunit of the interleukin 10 receptor. J Exp Med. (1998) 187:571-8. doi: 10.1084/jem.18 7.4.571

61. Zhu H, Lei X, Liu Q, Wang Y. Interleukin-10-1082A/G polymorphism and inflammatory bowel disease susceptibility: a meta-analysis based on 17,585 subjects. Cytokine. (2013) 61:146-53. doi: 10.1016/j.cyto.201 2.09.009

62. Moran CJ, Walters TD, Guo CH, Kugathasan S, Klein C, Turner D, et al. IL$10 \mathrm{R}$ polymorphisms are associated with very-early-onset ulcerative colitis. Inflamm Bowel Dis. (2013) 19:115-23. doi: 10.1002/ibd.22974

63. Franke A, Balschun T, Karlsen TH, Sventoraityte J, Nikolaus S, Mayr $\mathrm{G}$, et al. Sequence variants in IL10, ARPC2 and multiple other loci contribute to ulcerative colitis susceptibility. Nat Genet. (2008) 40:131923. doi: $10.1038 / \mathrm{ng} .221$

64. Madsen KL, Doyle JS, Tavernini MM, Jewell LD, Rennie RP, Fedorak RN. Antibiotic therapy attenuates colitis in interleukin 10 gene-deficient mice. Gastroenterology. (2000) 118:1094105. doi: 10.1016/S0016-5085(00)70362-3

65. Kullberg MC, Ward JM, Gorelick PL, Caspar P, Hieny S, Cheever $A$, et al. Helicobacter hepaticus triggers colitis in specific-pathogenfree interleukin-10 (IL-10)-deficient mice through an IL-12- and gamma interferon-dependent mechanism. Infect Immun. (1998) 66:5157-66. doi: 10.1128/IAI.66.11.5157-5166.1998

66. Low D, Nguyen DD, Mizoguchi E. Animal models of ulcerative colitis and their application in drug research. Drug Des Dev Ther. (2013) 7:134157. doi: 10.2147/DDDT.S40107

67. Powrie F, Leach MW, Mauze S, Menon S, Caddle LB, Coffman RL. Inhibition of Th1 responses prevents inflammatory bowel disease in scid mice reconstituted with CD45RBhi CD4 ${ }^{+}$T cells. Immunity. (1994) 1:55362. doi: 10.1016/1074-7613(94)90045-0 
68. Tomoyose M, Mitsuyama K, Ishida H, Toyonaga A, Tanikawa K. Role of interleukin-10 in a murine model of dextran sulfate sodium-induced colitis. Scand J Gastroenterol. (1998) 33:435-40. doi: 10.1080/00365529850171080

69. Rodrigues VF, Bahia MPS, Candido NR, Moreira JMP, Oliveira VG, Araujo ES, et al. Acute infection with Strongyloides venezuelensis increases intestine production IL-10, reduces Th1/Th2/Th17 induction in colon and attenuates dextran sulfate sodium-induced colitis in BALB/c mice. Cytokine. (2018) 111:72-83. doi: 10.1016/j.cyto.2018.08.003

70. Li B, Selmi C, Tang R, Gershwin ME, Ma X. The microbiome and autoimmunity: a paradigm from the gut-liver axis. Cell Mol Immunol. (2018) 15:595-609. doi: 10.1038/cmi.2018.7

71. Luu M, Pautz S, Kohl V, Singh R, Romero R, Lucas S, et al. The short-chain fatty acid pentanoate suppresses autoimmunity by modulating the metabolic-epigenetic crosstalk in lymphocytes. Nat Commun. (2019) 10:760. doi: 10.1038/s41467-019-08711-2

72. Sun M, Wu W, Chen L, Yang W, Huang $\mathrm{X}$, Ma C, et al. Microbiota-derived short-chain fatty acids promote Th1 cell IL-10 production to maintain intestinal homeostasis. Nat Commun. (2018) 9:3555. doi: 10.1038/s41467-018-05901-2

73. Rubtsov YP, Rasmussen JP, Chi EY, Fontenot J, Castelli L, $\mathrm{Ye} \mathrm{X}$, et al. Regulatory $\mathrm{T}$ cell-derived interleukin-10 limits inflammation at environmental interfaces. Immunity. (2008) 28:546-58. doi: 10.1016/j.immuni.2008.02.017

74. Chaudhry A, Samstein RM, Treuting P, Liang Y, Pils MC, Heinrich $\mathrm{JM}$, et al. Interleukin-10 signaling in regulatory $\mathrm{T}$ cells is required for suppression of Th17 cell-mediated inflammation. Immunity. (2011) 34:56678. doi: 10.1016/j.immuni.2011.03.018

75. Knochelmann HM, Dwyer CJ, Bailey SR, Amaya SM, Elston DM, Mazza-McCrann JM, et al. When worlds collide: Th17 and Treg cells in cancer and autoimmunity. Cell Mol Immunol. (2018) 15:45869. doi: 10.1038/s41423-018-0004-4

76. Chaudhry A, Rudra D, Treuting P, Samstein RM, Liang Y, Kas A, et al. $\mathrm{CD}^{+}$regulatory $\mathrm{T}$ cells control $\mathrm{TH} 17$ responses in a Stat3dependent manner. Science. (2009) 326:986-91. doi: 10.1126/science.11 72702

77. Li A, Gurung P, Malireddi RK, Vogel P, Kanneganti TD, Geiger TL. IL-10 engages macrophages to shift Th17 cytokine dependency and pathogenicity during T-cell-mediated colitis. Nat Commun. (2015) 6:6131. doi: $10.1038 /$ ncomms7131

78. Gurung P, Li B, Subbarao Malireddi RK, Lamkanfi M, Geiger TL, Kanneganti TD. Chronic TLR stimulation controls NLRP3 inflammasome activation through IL-10 mediated regulation of NLRP3 expression and caspase-8 activation. Sci Rep. (2015) 5:14488. doi: 10.1038/srep14488

79. Zigmond E, Bernshtein B, Friedlander G, Walker CR, Yona S, Kim KW, et al. Macrophage-restricted interleukin-10 receptor deficiency, but not IL10 deficiency, causes severe spontaneous colitis. Immunity. (2014) 40:72033. doi: 10.1016/j.immuni.2014.03.012

80. Shouval DS, Biswas A, Goettel JA, McCann K, Conaway E, Redhu NS, et al. Interleukin-10 receptor signaling in innate immune cells regulates mucosal immune tolerance and anti-inflammatory macrophage function. Immunity. (2014) 40:706-19. doi: 10.1016/j.immuni.2014.03.011

81. Koelink PJ, Bloemendaal FM, Li B, Westera L, Vogels EWM, van Roest $M$, et al. Anti-TNF therapy in IBD exerts its therapeutic effect through macrophage IL-10 signalling. Gut. (2019) 69:1053-63. doi: 10.1136/gutjnl-2019-318264

82. Li B, Alli R, Vogel P, Geiger TL. IL-10 modulates DSS-induced colitis through a macrophage-ROS-NO axis. Mucosal Immunol. (2014) 7:86978. doi: $10.1038 / \mathrm{mi} .2013 .103$

83. Shouval DS, Biswas A, Kang YH, Griffith AE, Konnikova L, Mascanfroni ID, et al. Interleukin lbeta mediates intestinal inflammation in mice and patients with interleukin 10 receptor deficiency. Gastroenterology. (2016) 151:1100-4. doi: 10.1053/j.gastro.2016.08.055

84. Ip WKE, Hoshi N, Shouval DS, Snapper S, Medzhitov R. Antiinflammatory effect of IL-10 mediated by metabolic reprogramming of macrophages. Science. (2017) 356:513-9. doi: 10.1126/science. aal3535

85. Kabat AM, Pearce EJ. Inflammation by way of macrophage metabolism. Science. (2017) 356:488-9. doi: 10.1126/science.aan2691
86. Xiao $\mathrm{P}$, Zhang $\mathrm{H}$, Zhang $\mathrm{Y}$, Zheng $\mathrm{M}$, Liu $\mathrm{R}$, Zhao $\mathrm{Y}$, et al. Phosphatase Shp2 exacerbates intestinal inflammation by disrupting macrophage responsiveness to interleukin-10. J Exp Med. (2019) 216:337-49. doi: 10.1084/jem.20181198

87. Guindi C, Cloutier A, Gaudreau S, Zerif E, McDonald PP, Tatsiy O, et al. Role of the p38 MAPK/C/EBPbeta pathway in the regulation of phenotype and IL-10 and IL-12 production by tolerogenic bone marrow-derived dendritic cells. Cells. (2018) 7:256. doi: 10.3390/cells7120256

88. Patterson AR, Endale M, Lampe K, Aksoylar HI, Flagg A, Woodgett JR, et al. Gimap5-dependent inactivation of GSK3beta is required for CD4(+) T cell homeostasis and prevention of immune pathology. Nat Commun. (2018) 9:430. doi: 10.1038/s41467-018-02897-7

89. Smith LK, Boukhaled GM, Condotta SA, Mazouz S, Guthmiller JJ, Vijay R, et al. Interleukin-10 directly inhibits CD8(+) T cell function by enhancing Nglycan branching to decrease antigen sensitivity. Immunity. (2018) 48:299312 e5. doi: 10.1016/j.immuni.2018.01.006

90. Dias AM, Correia A, Pereira MS, Almeida CR, Alves I, Pinto V, et al. Metabolic control of $\mathrm{T}$ cell immune response through glycans in inflammatory bowel disease. Proc Natl Acad Sci USA. (2018) 115:E465160. doi: 10.1073/pnas.1720409115

91. Brand S, Beigel F, Olszak T, Zitzmann K, Eichhorst ST, Otte JM, et al. IL-22 is increased in active Crohn's disease and promotes proinflammatory gene expression and intestinal epithelial cell migration. Am J Physiol Gastrointest Liver Physiol. (2006) 290:G827-38. doi: 10.1152/ajpgi.00513.2005

92. Sekikawa A, Fukui H, Suzuki K, Karibe T, Fujii S, Ichikawa K, et al. Involvement of the IL-22/REG Ialpha axis in ulcerative colitis. Lab Invest. (2010) 90:496-505. doi: 10.1038/labinvest.2009.147

93. Sugimoto K, Ogawa A, Mizoguchi E, Shimomura Y, Andoh A, Bhan AK, et al. IL-22 ameliorates intestinal inflammation in a mouse model of ulcerative colitis. J Clin Invest. (2008) 118:534-44. doi: 10.1172/JCI33194

94. Pickert G, Neufert C, Leppkes M, Zheng Y, Wittkopf N, Warntjen M, et al. STAT3 links IL-22 signaling in intestinal epithelial cells to mucosal wound healing. J Exp Med. (2009) 206:1465-72. doi: 10.1084/jem.20082683

95. Neufert C, Pickert G, Zheng Y, Wittkopf N, Warntjen M, Nikolaev A, et al. Activation of epithelial STAT3 regulates intestinal homeostasis. Cell Cycle. (2010) 9:652-5. doi: 10.4161/cc.9.4.10615

96. Zenewicz LA, Yancopoulos GD, Valenzuela DM, Murphy AJ, Stevens S, Flavell RA. Innate and adaptive interleukin-22 protects mice from inflammatory bowel disease. Immunity. (2008) 29:947-57. doi: 10.1016/j.immuni.2008.11.003

97. Geremia A, Arancibia-Carcamo CV, Fleming MP, Rust N, Singh B, Mortensen NJ, et al. IL-23-responsive innate lymphoid cells are increased in inflammatory bowel disease. J Exp Med. (2011) 208:1127-33. doi: 10.1084/jem.20101712

98. Sonnenberg GF, Artis D. Innate lymphoid cells in the initiation, regulation and resolution of inflammation. Nat Med. (2015) 21:698708. doi: 10.1038/nm.3892

99. Eberl G, Colonna M, Di Santo JP, McKenzie AN. Innate lymphoid cells. Innate lymphoid cells: a new paradigm in immunology. Science. (2015) 348:aaa6566. doi: 10.1126/science.aaa6566

100. Colonna M. Innate lymphoid cells: diversity, plasticity, and unique functions in immunity. Immunity. (2018) 48:110417. doi: 10.1016/j.immuni.2018.05.013

101. Wang X, Peng H, Tian Z. Innate lymphoid cell memory. Cell Mol Immunol. (2019) 16:423-9. doi: 10.1038/s41423-019-0212-6

102. Chen Y, Tian Z, Peng H. Immunological memory: ILC1s come into view. Cell Mol Immunol. (2019) 16:895-6. doi: 10.1038/s41423-019-0311-4

103. Wang S, Xia P, Chen Y, Qu Y, Xiong Z, Ye B, et al. Regulatory innate lymphoid cells control innate intestinal inflammation. Cell. (2017) 171:20116 e18. doi: 10.1016/j.cell.2017.07.027

104. Mielke LA, Groom JR, Rankin LC, Seillet C, Masson F, Putoczki T, et al. TCF-1 controls ILC2 and NKp46 ${ }^{+}$RORgammat $^{+}$innate lymphocyte differentiation and protection in intestinal inflammation. J Immunol. (2013) 191:4383-91. doi: 10.4049/jimmunol.1301228

105. Giacomin PR, Moy RH, Noti M, Osborne LC, Siracusa MC, Alenghat $\mathrm{T}$, et al. Epithelial-intrinsic IKKalpha expression regulates group 3 innate lymphoid cell responses and antibacterial immunity. J Exp Med. (2015) 212:1513-28. doi: 10.1084/jem.20141831 
106. Longman RS, Diehl GE, Victorio DA, Huh JR, Galan C, Miraldi ER, et al. CX(3)CR1(+) mononuclear phagocytes support colitis-associated innate lymphoid cell production of IL-22. J Exp Med. (2014) 211:157183. doi: $10.1084 /$ jem. 20140678

107. Qiu J, Guo X, Chen ZM, He L, Sonnenberg GF, Artis D, et al. Group 3 innate lymphoid cells inhibit T-cell-mediated intestinal inflammation through aryl hydrocarbon receptor signaling and regulation of microflora. Immunity. (2013) 39:386-99. doi: 10.1016/j.immuni.2013.08.002

108. Castellanos JG, Woo V, Viladomiu M, Putzel G, Lima S, Diehl GE, et al. Microbiota-induced TNF-like ligand 1A drives group 3 innate lymphoid cellmediated barrier protection and intestinal $\mathrm{T}$ cell activation during colitis. Immunity. (2018) 49:1077-89 e5. doi: 10.1016/j.immuni.2018.10.014

109. Li J, Shi W, Sun H, Ji Y, Chen Y, Guo X, et al. Activation of DR3 signaling causes loss of ILC3s and exacerbates intestinal inflammation. Nat Commun. (2019) 10:3371. doi: 10.1038/s41467-019-11304-8

110. Buonocore S, Ahern PP, Uhlig HH, Ivanov II, Littman DR, Maloy KJ, et al. Innate lymphoid cells drive interleukin-23-dependent innate intestinal pathology. Nature. (2010) 464:1371-5. doi: 10.1038/nature08949

111. Song C, Lee JS, Gilfillan S, Robinette ML, Newberry RD, Stappenbeck TS, et al. Unique and redundant functions of NKp46 ILC3s in models of intestinal inflammation. J Exp Med. (2015) 212:1869-82. doi: 10.1084/jem.20151403

112. Eken A, Singh AK, Treuting PM, Oukka M. IL-23R ${ }^{+}$innate lymphoid cells induce colitis via interleukin-22-dependent mechanism. Mucosal Immunol. (2014) 7:143-54. doi: 10.1038/mi.2013.33

113. Kamanaka M, Huber S, Zenewicz LA, Gagliani N, Rathinam C, O'Connor W $\mathrm{Jr}$, et al. Memory/effector (CD45RB(lo)) CD4 T cells are controlled directly by IL-10 and cause IL-22-dependent intestinal pathology. J Exp Med. (2011) 208:1027-40. doi: 10.1084/jem.20102149

114. Bauche D, Joyce-Shaikh B, Jain R, Grein J, Ku KS, Blumenschein WM, et al. LAG3(+) regulatory T cells restrain interleukin-23-producing CX3CR1(+) gut-resident macrophages during group 3 innate lymphoid cell-driven colitis. Immunity. (2018) 49:342-52 e5. doi: 10.1016/j.immuni.2018.07.007

115. Mannino MH, Zhu Z, Xiao H, Bai Q, Wakefield MR, Fang Y. The paradoxical role of IL-10 in immunity and cancer. Cancer Lett. (2015) 367:103-7. doi: 10.1016/j.canlet.2015.07.009

116. Boyano MD, Garcia-Vazquez MD, Lopez-Michelena T, Gardeazabal J, Bilbao J, Canavate ML, et al. Soluble interleukin-2 receptor, intercellular adhesion molecule-1 and interleukin-10 serum levels in patients with melanoma. $\mathrm{Br} J$ Cancer. (2000) 83:847-52. doi: 10.1054/bjoc.2000.1402

117. Chen Q, Daniel V, Maher DW, Hersey P. Production of IL-10 by melanoma cells: examination of its role in immunosuppression mediated by melanoma. Int J Cancer. (1994) 56:755-60. doi: 10.1002/ijc.2910560524

118. Sawant DV, Yano H, Chikina M, Zhang Q, Liao M, Liu C, et al. Adaptive plasticity of IL-10(+) and IL-35(+) Treg cells cooperatively promotes tumor $\mathrm{T}$ cell exhaustion. Nat Immunol. (2019) 20:72435. doi: 10.1038/s41590-019-0346-9

119. Berg DJ, Davidson N, Kuhn R, Muller W, Menon S, Holland G, et al. Enterocolitis and colon cancer in interleukin-10-deficient mice are associated with aberrant cytokine production and $\mathrm{CD} 4(+)$ TH1-like responses. J Clin Invest. (1996) 98:1010-20. doi: 10.1172/JCI118861

120. Brennan CA, Garrett WS. Gut microbiota, inflammation, colorectal cancer. Annu Rev Microbiol. (2016) 70:395411. doi: 10.1146/annurev-micro-102215-095513

121. Shattuck-Brandt RL, Varilek GW, Radhika A, Yang F, Washington MK, DuBois RN. Cyclooxygenase 2 expression is increased in the stroma of colon carcinomas from IL-10(-/-) mice. Gastroenterology. (2000) 118:33745. doi: 10.1016/S0016-5085(00)70216-2

122. Im E, Jung J, Pothoulakis C, Rhee SH. Disruption of Pten speeds onset and increases severity of spontaneous colitis in Il10(-/-) mice. Gastroenterology. (2014) 147:667-79 e10. doi: 10.1053/j.gastro.2014.05.034

123. Gunasekera DC, Ma J, Vacharathit V, Shah P, Ramakrishnan A, Uprety P, et al. The development of colitis in Il10(-/-) mice is dependent on IL-22. Mucosal Immunol. (2020) 13:493-506. doi: 10.1038/s41385-019-0252-3

124. Yan G, Liu T, Yin L, Kang Z, Wang L. Levels of peripheral Th17 cells and serum Th17-related cytokines in patients with colorectal cancer: a metaanalysis. Cell Mol Biol. (2018) 64:94-102. doi: 10.14715/cmb/2018.64.6.16
125. Grivennikov SI, Wang K, Mucida D, Stewart CA, Schnabl B, Jauch D, et al. Adenoma-linked barrier defects and microbial products drive IL-23/IL-17-mediated tumour growth. Nature. (2012) 491:254-8. doi: 10.1038/nature11465

126. Dong C. TH17 cells in development: an updated view of their molecular identity and genetic programming. Nat Rev Immunol. (2008) 8:33748. doi: $10.1038 /$ nri2295

127. Chung Y, Chang SH, Martinez GJ, Yang XO, Nurieva R, Kang HS, et al. Critical regulation of early Th17 cell differentiation by interleukin-1 signaling. Immunity. (2009) 30:576-87. doi: 10.1016/j.immuni.2009.02.007

128. Xiao H, Gulen MF, Qin J, Yao J, Bulek K, Kish D, et al. The Toll-interleukin-1 receptor member SIGIRR regulates colonic epithelial homeostasis, inflammation, and tumorigenesis. Immunity. (2007) 26:46175. doi: 10.1016/j.immuni.2007.02.012

129. Wang Y, Wang K, Han GC, Wang RX, Xiao H, Hou CM, et al. Neutrophil infiltration favors colitis-associated tumorigenesis by activating the interleukin-1 (IL-1)/IL-6 axis. Mucosal Immunol. (2014) 7:110615. doi: $10.1038 / \mathrm{mi} .2013 .126$

130. Mohamed E, Al-Khami AA, Rodriguez PC. The cellular metabolic landscape in the tumor milieu regulates the activity of myeloid infiltrates. Cell Mol Immunol. (2018) 15:421-7. doi: 10.1038/s41423-018-0001-7

131. Grivennikov S, Karin E, Terzic J, Mucida D, Yu GY, Vallabhapurapu S, et al. IL-6 and Stat3 are required for survival of intestinal epithelial cells and development of colitis-associated cancer. Cancer Cell. (2009) 15:10313. doi: 10.1016/j.ccr.2009.01.001

132. Lasry A, Zinger A, Ben-Neriah Y. Inflammatory networks underlying colorectal cancer. Nat Immunol. (2016) 17:230-40. doi: 10.1038/ni.3384

133. Angevin E, Tabernero J, Elez E, Cohen SJ, Bahleda R, van Laethem JL, et al. A phase I/II, multiple-dose, dose-escalation study of siltuximab, an antiinterleukin-6 monoclonal antibody, in patients with advanced solid tumors. Clin Cancer Res. (2014) 20:2192-204. doi: 10.1158/1078-0432.CCR-13-2200

134. Huber S, Gagliani N, Zenewicz LA, Huber FJ, Bosurgi L, Hu B, et al. IL22BP is regulated by the inflammasome and modulates tumorigenesis in the intestine. Nature. (2012) 491:259-63. doi: 10.1038/nature11535

135. Dmitrieva-Posocco O, Dzutsev A, Posocco DF, Hou V, Yuan W, Thovarai V, et al. Cell-type-specific responses to interleukin-1 control microbial invasion and tumor-elicited inflammation in colorectal cancer. Immunity. (2019) 50:166-80 e7. doi: 10.1016/j.immuni.2018.11.015

136. Hernandez P, Gronke K, Diefenbach A. A catch-22: interleukin-22 and cancer. Eur J Immunol. (2018) 48:15-31. doi: 10.1002/eji.201747183

137. Leon-Cabrera S, Vazquez-Sandoval A, Molina-Guzman E, Delgado-Ramirez Y, Delgado-Buenrostro NL, Callejas BE, et al. Deficiency in STAT1 signaling predisposes gut inflammation and prompts colorectal cancer development. Cancers. (2018) 10:341. doi: 10.3390/cancers10090341

138. Thompson CL, Plummer SJ, Tucker TC, Casey G, Li L. Interleukin-22 genetic polymorphisms and risk of colon cancer. Cancer Causes Control. (2010) 21:1165-70. doi: 10.1007/s10552-010-9542-5

139. Doulabi H, Rastin M, Shabahangh H, Maddah G, Abdollahi A, Nosratabadi R, et al. Analysis of Th22, Th17 and CD4(+)cells co-producing IL-17/IL22 at different stages of human colon cancer. Biomed Pharmacother. (2018) 103:1101-6. doi: 10.1016/j.biopha.2018.04.147

140. Kirchberger S, Royston DJ, Boulard O, Thornton E, Franchini F, Szabady $\mathrm{RL}$, et al. Innate lymphoid cells sustain colon cancer through production of interleukin-22 in a mouse model. J Exp Med. (2013) 210:91731. doi: $10.1084 /$ jem. 20122308

141. Lim C, Savan R. The role of the IL-22/IL-22R1 axis in cancer. Cytokine Growth Factor Rev. (2014) 25:257-71. doi: 10.1016/j.cytogfr.2014.04.005

142. Khare V, Paul G, Movadat O, Frick A, Jambrich M, Krnjic A, et al. IL10R2 overexpression promotes IL22/STAT3 signaling in colorectal carcinogenesis. Cancer Immunol Res. (2015) 3:1227-35. doi: 10.1158/2326-6066.CIR-15-0031

143. Bollrath J, Phesse TJ, von Burstin VA, Putoczki T, Bennecke M, Bateman T, et al. gp130-mediated Stat3 activation in enterocytes regulates cell survival and cell-cycle progression during colitis-associated tumorigenesis. Cancer Cell. (2009) 15:91-102. doi: 10.1016/j.ccr.2009.01.002

144. Putoczki TL, Thiem S, Loving A, Busuttil RA, Wilson NJ, Ziegler PK, et al. Interleukin-11 is the dominant IL-6 family cytokine during gastrointestinal 
tumorigenesis and can be targeted therapeutically. Cancer Cell. (2013) 24:257-71. doi: 10.1016/j.ccr.2013.06.017

145. Kryczek A, Lin Y, Nagarsheth N, Peng D, Zhao L, Zhao E, et al. IL$22(+) \mathrm{CD} 4(+) \mathrm{T}$ cells promote colorectal cancer stemness via STAT3 transcription factor activation and induction of the methyltransferase DOT1L. Immunity. (2014) 40:772-84. doi: 10.1016/j.immuni.2014.03.010

146. Koltsova EK, Grivennikov SI. IL-22 gets to the stem of colorectal cancer. Immunity. (2014) 40:639-41. doi: 10.1016/j.immuni.2014.04.014

147. Barker N, van Es JH, Kuipers J, Kujala P, van den Born M, Cozijnsen M, et al. Identification of stem cells in small intestine and colon by marker gene Lgr5. Nature. (2007) 449:1003-7. doi: 10.1038/nature06196

148. Aparicio-Domingo P, Romera-Hernandez M, Karrich JJ, Cornelissen F, Papazian N, Lindenbergh-Kortleve DJ, et al. Type 3 innate lymphoid cells maintain intestinal epithelial stem cells after tissue damage. J Exp Med. (2015) 212:1783-91. doi: 10.1084/jem.20150318

149. Lindemans CA, Calafiore M, Mertelsmann AM, O'Connor MH, Dudakov $\mathrm{JA}$, Jenq RR, et al. Interleukin-22 promotes intestinal-stem-cell-mediated epithelial regeneration. Nature. (2015) 528:560-4. doi: 10.1038/nature16460

150. Jiang R, Wang H, Deng L, Hou J, Shi R, Yao M, et al. IL-22 is related to development of human colon cancer by activation of STAT3. BMC Cancer. (2013) 13:59. doi: 10.1186/1471-2407-13-59

151. Kobold S, Volk S, Clauditz T, Kupper NJ, Minner S, Tufman A, et al. Interleukin-22 is frequently expressed in small- and large-cell lung cancer and promotes growth in chemotherapy-resistant cancer cells. J Thorac Oncol. (2013) 8:1032-42. doi: 10.1097/JTO.0b013e31829923c8

152. Wang C, Gong G, Sheh A, Muthupalani S, Bryant EM, Puglisi DA, et al. Interleukin-22 drives nitric oxide-dependent DNA damage and dysplasia in a murine model of colitis-associated cancer. Mucosal Immunol. (2017) 10:1504-17. doi: 10.1038/mi.2017.9

153. Chernoff AE, Granowitz EV, Shapiro L, Vannier E, Lonnemann G, Angel JB, et al. A randomized, controlled trial of IL-10 in humans. Inhibition of inflammatory cytokine production and immune responses. J Immunol. (1995) 154:5492-9.

154. Schreiber S, Fedorak RN, Nielsen OH, Wild G, Williams CN, Nikolaus S, et al. Safety and efficacy of recombinant human interleukin 10 in chronic active Crohn's disease. Crohn's Disease IL-10 Cooperative Study Group. Gastroenterology. (2000) 119:1461-72. doi: 10.1053/gast.2000.20196

155. Colombel JF, Rutgeerts P, Malchow H, Jacyna M, Nielsen OH, Rask-Madsen $\mathrm{J}$, et al. Interleukin 10 (Tenovil) in the prevention of postoperative recurrence of Crohn's disease. Gut. (2001) 49:42-6. doi: 10.1136/gut.49.1.42

156. Lauw FN, Pajkrt D, Hack CE, Kurimoto M, van Deventer SJ, van der Poll T. Proinflammatory effects of IL-10 during human endotoxemia. J Immunol. (2000) 165:2783-9. doi: 10.4049/jimmunol.165.5.2783

157. Buruiana FE, Sola I, Alonso-Coello P. Recombinant human interleukin 10 for induction of remission in Crohn's disease. Cochrane Database Syst Rev. (2010) 2010:CD005109. doi: 10.1002/14651858.CD005109.pub3

158. Schwager K, Kaspar M, Bootz F, Marcolongo R, Paresce E, Neri D, et al. Preclinical characterization of DEKAVIL (F8-IL10), a novel clinical-stage immunocytokine which inhibits the progression of collageninduced arthritis. Arthritis Res Ther. (2009) 11:R142. doi: 10.1186/ ar2814

159. Naing A, Papadopoulos KP, Autio KA, Ott PA, Patel MR, Wong DJ, et al. Safety, antitumor activity, and immune activation of pegylated recombinant human interleukin-10 (AM0010) in patients with advanced solid tumors. J Clin Oncol. (2016) 34:3562-9. doi: 10.1200/JCO.2016.6 8.1106

160. Steidler L, Hans W, Schotte L, Neirynck S, Obermeier F, Falk W, et al. Treatment of murine colitis by Lactococcus lactis secreting interleukin-10. Science. (2000) 289:1352-5. doi: 10.1126/science.289.5483. 1352
161. Innocentin S, Guimaraes V, Miyoshi A, Azevedo V, Langella P, Chatel JM, et al. Lactococcus lactis expressing either Staphylococcus aureus fibronectinbinding protein A or Listeria monocytogenes internalin A can efficiently internalize and deliver DNA in human epithelial cells. Appl Environ Microbiol. (2009) 75:4870-8. doi: 10.1128/AEM.00825-09

162. Shanahan F. Immunology. Therapeutic manipulation of gut flora. Science. (2000) 289:1311-2. doi: 10.1126/science.289.5483.1311

163. van Deventer SJ, Elson CO, Fedorak RN. Multiple doses of intravenous interleukin 10 in steroid-refractory Crohn's disease. Crohn's Disease Study Group. Gastroenterology. (1997) 113:383-9. doi: 10.1053/gast.1997.v113.pm9247454

164. Miyoshi A, Jamet E, Commissaire J, Renault P, Langella P, Azevedo V. A xylose-inducible expression system for Lactococcus lactis. FEMS Microbiol Lett. (2004) 239:205-12. doi: 10.1016/j.femsle.2004.08.018

165. del Carmen S, Martin Rosique R, Saraiva T, Zurita-Turk M, Miyoshi A, Azevedo V, et al. Protective effects of lactococci strains delivering either IL-10 protein or CDNA in a TNBS-induced chronic colitis model. J Clin Gastroenterol. (2014) 48:S12-7. doi: 10.1097/MCG.0000000000000235

166. del Carmen S, de Moreno de LeBlanc A, Perdigon G, Bastos Pereira V, Miyoshi A, Azevedo V, et al. Evaluation of the anti-inflammatory effect of milk fermented by a strain of IL-10-producing Lactococcus lactis using a murine model of Crohn's disease. J Mol Microbiol Biotechnol. (2011) 21:138-46. doi: 10.1159/000333830

167. O'Garra A, Barrat FJ, Castro AG, Vicari A, Hawrylowicz C. Strategies for use of IL-10 or its antagonists in human disease. Immunol Rev. (2008) 223:114-31. doi: 10.1111/j.1600-065X.2008.00635.x

168. Naing A, Infante JR, Papadopoulos KP, Chan IH, Shen C, Ratti NP, et al. PEGylated IL-10 (pegilodecakin) induces systemic immune activation, $\mathrm{CD} 8(+) \mathrm{T}$ cell invigoration and polyclonal $\mathrm{T}$ cell expansion in cancer patients. Cancer Cell. (2018) 34:775-91 e3. doi: 10.1016/j.ccell.2018.10.007

169. Sturlan S, Oberhuber G, Beinhauer BG, Tichy B, Kappel S, Wang $\mathrm{J}$, et al. Interleukin-10-deficient mice and inflammatory bowel disease associated cancer development. Carcinogenesis. (2001) 22:665-71. doi: 10.1093/carcin/22.4.665

170. Wang X, Wong K, Ouyang W, Rutz S. Targeting IL-10 family cytokines for the treatment of human diseases. Cold Spring Harbor Perspect Biol. (2019) 11:a028548. doi: 10.1101/cshperspect.a028548

171. Goto Y, Obata T, Kunisawa J, Sato S, Ivanov II, Lamichhane A, et al. Innate lymphoid cells regulate intestinal epithelial cell glycosylation. Science. (2014) 345:1254009. doi: 10.1126/science.1254009

172. Tang KY, Lickliter J, Huang ZH, Xian ZS, Chen HY, Huang C, et al. Safety, pharmacokinetics, and biomarkers of F-652, a recombinant human interleukin-22 dimer, in healthy subjects. Cell Mol Immunol. (2019) 16:47382. doi: 10.1038/s41423-018-0029-8

173. Stefanich EG, Rae J, Sukumaran S, Lutman J, Lekkerkerker A, Ouyang W, et al. Pre-clinical and translational pharmacology of a human interleukin-22 IgG fusion protein for potential treatment of infectious or inflammatory diseases. Biochem Pharmacol. (2018) 152:224-35. doi: 10.1016/j.bcp.2018.03.031

Conflict of Interest: The authors declare that the research was conducted in the absence of any commercial or financial relationships that could be construed as a potential conflict of interest.

Copyright (C) 2020 Wei, Wang and Li. This is an open-access article distributed under the terms of the Creative Commons Attribution License (CC BY). The use, distribution or reproduction in other forums is permitted, provided the original author(s) and the copyright owner(s) are credited and that the original publication in this journal is cited, in accordance with accepted academic practice. No use, distribution or reproduction is permitted which does not comply with these terms. 